\title{
US and British researchers agree not to seek gene fragment patents
}

Washington. The National Institutes of Health (NIH) made an eleventh-hour decision last week not to appeal a ruling by the US Patent and Trademark Office (PTO) rejecting its application for patents on some two thousand human gene fragments.

The NIH had been given until midnight last Thursday to lodge an appeal against the decision. It also announced its intention to withdraw a pending patent application on a further 4,448 complementary DNA (cDNA) sequences, in addition to any foreign patent applications.

The day after NIH's decision, the UK Medical Research Council (MRC), which had previously offered to suspend its own patent applications if the NIH acted in a similar way, announced plans to follow suit.

After seeking the advice of government officials, lawyers, representatives from industry and scientists, Harold Varmus, the director of NIH, concluded that pursuing patents on partial or full-length gene se- quences whose function and practical utility are unknown was neither in the public nor scientific interest, and "seemed like a very poor use of government money".

Rather than promoting the transfer of scientific results out of the laboratory, Varmus said that pursuing the matter further could hamper research collaborations, both in the United States and abroad.

In June 1991, a decision by Bernadine Healy, then the director of NIH, to file for patent rights on 315 human cDNA sequences sparked off a storm of controversy among academic scientists and officials in industry. Two further patent filings were made, bringing the total number of sequences claimed to almost 7,000.

Healy defended her actions by saying that they were needed to protect the commercial interests of NIH while the Patent Office grappled with the issue of whether the patents could in fact be granted. In what was seen as a largely defensive move, Brit-

\section{Funding cuts favour industry links}

Washington. The rate of growth of US spending on research and development has slowed to an average of only 0.9 per cent a year, one-sixth of that during the period 1975-85, according to a report published last week by the National Science Board.

But Science and Engineering Indicators 1993 - a biannual survey of US research trends - finds that academic researchers are responding to the more stringent financial climate by forging closer links with industry.

The proportion of academic research funded by the federal government had fallen to 55 per cent last year from 67 per cent in 1980. But funds from the universities themselves and from industry grew to fill the gap, with the latter doubling to 7 per cent.

The United States retains a comfortable lead over its competitors in research and development, with twice as many working scientists and engineers as Japan, and more industrial research and development than all countries of the European Union combined. Its total spending of $\$ 161$ billion last year exceeded that of Japan, France and Germany put together, the report says.

But ominously for the longer term from a US point of view, the report also points out that six Asian countries are between them now producing half-a-million science and engineering graduates a year - more than Europe and North America combined.

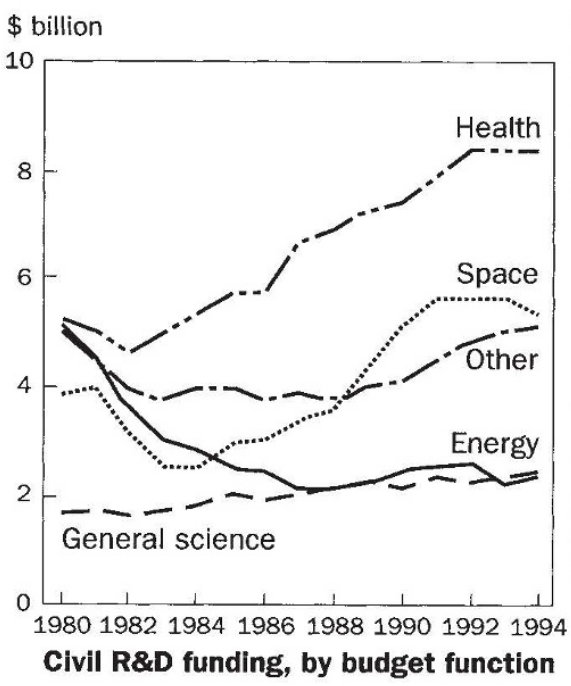

Following cuts in defence spending, previous shortages of key scientific personnel have given way to a rise in unemployment, which has reached 3 per cent and 3.7 per cent among US scientists and engineers respectively, the report says.

It predicts that surpluses of scientists are more likely than shortages in the coming years. But the growth in wages remains strong, and the number of scientists coming to work permanently in the United States increased dramatically to 23,000 in 1992 - about double the previous annual rate.

Colin Macilwain ain's MRC filed for its own patents, in case the NIH patents were granted.

Last August, the patent office rejected NIH's claims on 2,421 sequences for the second time, and gave NIH six months to appeal.

The sequences were generated using a technique for the rapid sequencing of cDNA developed by Craig Venter while he worked at NIH's National Institute of Neurological Disorders and Stroke. Venter's collection of sequences ranged from non-coding sequences to partial and, in a few cases, fulllength coding sequences.

Some of the fragments have the potential to encode protein sequences that can be recognised as being in the same functional class. But Varmus says he does not consider that to be a "functional definition that has practical value - has utility".

The consensus of a meeting of company representatives, government officials, lawyers and scientists held at NIH last December seemed in favour of an appeal. One dissenter from this position was Rebecca Eisenberg, a law professor at the University of Michigan Law School.

Although there appeared to be a consensus at the meeting, Eisenberg says those present all had very different ideas of what they hoped to accomplish by appealing. In a subsequent letter to Varmus, Eisenberg put forward some persuasive arguments against such action, which Varmus says weighed heavily in his final decision. In particular, Eisenberg says she stressed that any decision to come out of an appeal by NIH was unlikely to resolve the matter (as to what is and is not patentable) once and for all.

News of NIH's decision has generated a collective sigh of relief among many academic scientists. C. Thomas Caskey, international president of the Human Genome Organisation (HUGO) and director and investigator at the Institute for Molecular Genetics, Baylor College of Medicine, says Varmus's decision "is wholeheartedly supported by HUGO".

At a recent $\mathrm{HUGO}$ summit conference held last month in Houston, Caskey says wide support was given to the notion that the standard for patentability of cDNAs should be "utility based". Unless something can be said about function and utility, patents on even the full-length gene sequence should not be supported, he says.

In his final decision, Varmus seemed to concur with this view. Caskey says that the problem, however, is that US patent law places greater emphasis on chemical composition than utility.

Diane Gershon 